\title{
Blackwell
}

Reference Online

\section{Bibliographic Details}

\section{The Handbook of Communication and Corporate Social Responsibility}

Edited by: Øyvind Ihlen, Jennifer L. Bartlett and Steve May

eISBN: 9781444336344

Print publication date: 2011

\section{Corporate Social Responsibility and Communication}

\author{
Øyvind Ihlen, Jennifer L. Bartlett and Steve May
}

Subject Communication and Media Studies

DOI: $\quad 10.1111 /$ b. $\quad 1781444336344.2011 .00002 . x$

\section{Sections}

- The Literature on CSR Communication

- Defining CSR and CSR Communication: Background and History

- Criticism of CSR and CSR Communication

- The Importance of Communication

- Structure of the Book

- References

\begin{abstract}
Corporate activities are increasingly scrutinized for their effect on society and the environment. It is unthinkable that a corporation today will declare publicly that its only goal is to make money for its shareholders. Instead, corporations typically claim to balance the needs of society and the environment against the need to make a profit. That is, corporations say they practice corporate social responsibility (CSR). This edited volume explores the complexities of this seemingly simple claim. As such it is an essential resource to complement the latest academic thinking from management and communication research on how corporations communicate about CSR. This chapter presents an overview of the book.
\end{abstract}

While there is a huge literature on corporate social responsibility (CSR), the literature on CSR communication is disproportionate in size, with relatively little cross-disciplinary research on the topic. This book aims to be the definitive research collection for CSR communication by pulling together and expanding on existing recommendations from the management discipline and from communication disciplines such as public relations, organizational communication, marketing, and reputation management. Scholars from all these disciplines contribute to the book and together show how such notions as dialogue, trust, discourse, reputation and rhetoric enrich our understanding of CSR communication and influence the way organizations should be managed. The contributors to the book were also asked to provide suggestions for future research, something we consider to be a crucial feature of the book. We also make the case that CSR, and CSR 
communication specifically, should be studied in its own right. The central role corporations have in society merits research in itself as corporations have the ability to influence our daily lives in myriad ways.

In this introductory chapter we first give a short overview of the literature on CSR communication and present the rationale for the book. Then we briefly explain what we mean by CSR, discuss the criticism of the concept and spell out why we think communication has such a crucial role in relation to CSR. The final part of the chapter gives an overview of the structure and content of the book.

\section{The Literature on CSR Communication}

CSR is a highly fashionable management concept and something modern managers ignore at their own peril (Porter and Kramer, 2006; Zorn and Collins, 2007). With a few exceptions (e.g., den Hond, de Bakker, and Neergaard, 2007; Smith, Vogel, and Levine, 2010), however, management books are largely silent on the topic of CSR communication. Textbooks like Corporate Responsibility: A Critical Introduction (Blowfield and Murray, 2008) and Strategic Corporate Social Responsibility: Stakeholders in a Global Environment (Werther and Chandler, 2006), typically relegate communication a role in the periphery. The situation is the same in research volumes like The Oxford Handbook of Corporate Social Responsibility (Crane, McWilliams, Matten et al., 2008b), Global Practices of Corporate Social Responsibility (Idowu and Filho, 2009), Corporate Social Responsibility Across Europe (Habisch, Jonker, Wegner, and Schmidpeter, 2005), Developing Corporate Social Responsibility: A European Perspective (Perrini, Pogutz, and Tencati, 2006), and A Handbook of Corporate Governance and Social Responsibility (Aras and Crowther, 2010).

It does not help, either, to look at books that deal with related concepts like corporate citizenship, for example, Handbook of Research on Global Corporate Citizenship (Scherer and Palazzo, 2008). When communication is actually mentioned in this literature, the communication ideal that is implied is often ill-defined and vague. Calls are issued for corporations to engage in stakeholder dialogue and implement transparency/accountability through the publication of nonfinancial reports, but the books seldom mine the insights that can be culled from communication disciplines in this regard.

The situation is better in some of the management journals, particularly in business ethics. Scholars have been particularly occupied with nonfinancial reports (e.g., Aras and Crowther, 2009; Campbell, Shrives, and Bohmbach-Saager, 2001; Clarke and Gibson-Sweet, 1999; Hartman, Rubin, and Dhanda, 2007; Perrini, 2005), communication of corporate ethic codes (e.g., Painter-Morland, 2006; Svensson, Wood, Singh et al., 2009a; Svensson, Wood, Singh et al., 2009b), and stakeholder dialogue processes (e.g., Burchell and Cook, 2006, 2008; Morsing and Schultz, 2006). The list grows longer if we include studies of communication of sustainability (e.g., Jose and Lee, 2007; Kolk, 2003; Livesey and Kearins, 2002).

But again, many of the studies remain in their silos with little or no reference to communication theory or practice (e.g., Du, Bhattacharya, and Sen, 2010).

Actually turning to the communication disciplines, work on CSR communication has been published in journals within fields such as public relations (e.g., Bernays, 1975; Golob and Bartlett, 2007; Wang and Chaudhri, 2009), corporate communication (e.g., Birth, Illia, Lurati et al., 2008; Branco and Rodrigues, 2006; Nielsen and Thomsen, 2007), organizational communication (e.g., Chaudhri and Jian, 2007), marketing communication (e.g., Morsing, Schultz, and Nielsen, 2008; Podnar, 2008), communication management (e.g., Moreno and Capriotti, 2009), and reputation management (e.g., Fombrun, 2005; Hagen, 2008). These and other contributions will be thoroughly reviewed in the following chapters.

To date and to our knowledge, communication scholars have published one textbook on CSR, Corporate Social Responsibility: Virtue or Vice? (May, 2011), and three edited volumes: Strategic CSR Communication (Morsing and Beckmann, 2006), The Debate Over Corporate Social Responsibility (May, Cheney, and Roper, 2007), and Handbuch Corporate Social Responsibility: Kommunikationswissenschaftliche Grundlagen und Methodische Zugänge [Handbook of Corporate Social Responsibility: Theoretical Foundation and Methodological Approaches from Communication Studies] (Raupp, Jarolimek, and Schultz, 2010). The first of these edited, scholarly books raises key issues and challenges that managers face as organizations engage in stakeholder dialogues. The book is very useful, but most of the empirical material is related to Denmark, thus limiting its scope. The title of the second book, The Debate Over Corporate Social Responsibility, gives away the fact that the primary emphasis of the volume is on conceptual foundations for the study of CSR. In other words, the book only contains a few chapters on CSR communication, as such, and stops short of pointing out recommendations for CSR communication. The third book touches on basic concepts of CSR communication, CSR in public communication, interdisciplinary approaches, methodological approaches and case studies. However, the book is published in German and largely focuses on German empirical material, thus limiting its scope and reach.

Taken together then, there has been valuable work on CSR communication in both management and 
communication and more detailed over views are presented in chapters to follow. Still, we argue that the work often stays within the limits of its discipline and, furthermore, that it has not reached a critical mass where it has had an impact on mainstream management textbooks. Our goal with this volume is thus to (1) move beyond the scattered journal articles in order to present, discuss and extend on the state-of-the-art insights on CSR communication, and (2) to demonstrate how this research has implications for the strategic management of organizations. As mentioned, we also maintain that CSR and CSR communication deserves to be studied in its own right, since it is such a prominent feature of current business life. The larger backdrop here is the recognition that corporations have become today's dominating social institution (Deetz, 1992; Korten, 2001).

\section{Defining CSR and CSR Communication: Background and History}

Several concepts have been launched to describe the relationship between business and society (see, Elkington, 1998; Henriques and Richardson, 2004; Waddock, 2004; Wood, 1991 a). Corporate citizenship is one such notion that has been particularly popular (Waddock, 2001; Windsor, 2001). A journal is dedicated to this concept - Journal of Corporate Citizenship - and large corporations like ExxonMobil and General Electric use the term (e.g., ExxonMobil, 2010; General Electric Company, 2010). Scholars typically point to how corporate citizenship can help to focus on the political role of the corporation, but also that the citizenship concept implies that the corporation has rights, too. Still, the concept has its fair share of detractors, criticizing it for being fundamentally instrumental and self-serving, and masking the profound role of corporations in society (Matten, Crane, and Chapple, 2003; Windsor, 2001).

Several authors prefer to use the term corporate responsibility (e.g., Chen and Bouvain, 2009; Heath and Palenchar, 2008; Hillenbrand and Money, 2007). This is also the term favored by large corporations like Chevron (2010) and ING Group (2010). Probably the best argument for using corporate responsibility is that the term directs attention to how the responsibilities of business extend to the economic sphere and the environment. The latter point is also implicated in the number of large corporations that prefer the term sustainability when they issue their nonfinancial reports. Examples include Shell (2010), BP (2010), and Ford (2010).

Our decision to use CSR, however, is rooted partly in our agreement with the criticism of the corporate citizenship concept, and partly in the pragmatic reason that most of the research literature uses this term (e.g., Burchell, 2008; Crane, Matten, and Spence, 2008; Crane, McWilliams, Matten et al., 2008b; Crowther and Rayman-Bacchus, 2004b; den Hond et al., 2007; Habisch et al., 2005; Idowu and Filho, 2009; May et al., 2007; Vogel, 2005; Werther and Chandler, 2006). The term is also frequently used in business, including large corporations like China National Petroleum Corporation (2010). CSR is still "a dominant, if not exclusive, term in the academic literature and in business practice" (Carroll and Shabana, 2010, p. 86). (See also Chapter 2 and Chapter 3 for different takes on this discussion.)

CSR has a relatively long tradition rooted in notions of philanthropy, but also as a reaction against business' social transgression (Mitchell, 1989). Still, it is the 1953 book Social Responsibility of the Businessman by Howard R. Bowen that is most frequently credited as laying the foundation for CSR thinking (Carroll, 1999). Many scholars agree that the notion gained foothold during the 1960s as a form of business response to new and stronger social demands (Buchholz and Rosenthal, 1999/2002; Carroll, 1999; Wood, 1991b). Since the late 1990s, however, the relationship between business and society has been discussed with more vigor than before, partly as a consequence of globalization. Many Western companies have increased their presence in new provinces with democratic deficits, questionable human rights records, and widespread corruption. Should the companies take steps to root out such practices, or should this be left to civil society and the governments in the host countries? In addition, both large and small companies face increasing domestic challenges related to the environment, outsourcing and contracting, as well as corruption and other forms of economic crime.

While the argument has been sounded that business should concentrate on legal ways to make profit for its owners (Crook, 2005; Friedman, 1970; Henderson, 2001; Levitt, 1958), the business world has embraced the CSR concept. Among the companies on the Global Fortune 250 list, nonfinancial reporting has become the norm rather than the exception. Nearly 80 percent of these companies issue such reports (KPMG, 2008). Influential institutions such as the United Nations, the European Union, the Organization of Economic Co-Operation and Development (OECD), and the World Bank support the notion, and even critics recognize that "for most managers the only real question about CSR is how to do it" (The Economist, 2008, p. 12).

While CSR at a minimum implies that businesses have responsibilities beyond profit-seeking, the notion is still ambiguous. There is no dominant paradigm of CSR and no commonly agreed upon definition (Crane, McWilliams, Matten et al., 2008a; Crowther and Rayman-Bacchus, 2004a; Lockett, Moon, and Visser, 2006; 
McWilliams, Siegel, and Wright, 2006). One take on the topic is that business earns its "license to operate" from civil society and must act in accordance with accepted social norms to prosper and survive in the long term. The social nature of expectations regarding CSR is illustrated by how conduct that was previously acceptable, is now criticized in the media. Business must take into consideration and attempt to avoid or rectify the harmful effects of its activities.

CSR is an "essentially contested concept" which means that it is also flexible (Okoye, 2009, p. 624). CSR can be defined as a field of scholarship (Crane, McWilliams, Matten et al., 2008a) or as a business strategy of dealing with the social and environmental context (Commission of the European Communities, 2001; Perrini et al., 2006; Vogel, 2005). Some like to add a normative dimension and argue that CSR is about conducting business "in a manner that meets high social and environmental standards" (Fisher and Lovell, 2003, p. 37).

Many scholars maintain that CSR goes beyond compliance with the law (McWilliams et al., 2006; Perrini et al., 2006). Others argue that a CSR definition should also include economic and legal expectations (Carroll, 1979, 1991; Carroll and Shabana, 2010): A company must meet its responsibilities in the economic sphere, that is, towards shareholders, employees and customers. In the legal sphere, it is required that the company conducts its business within the framework of the law. Furthermore, it is expected that companies behave ethically, and it is desired that they engage in discretionary and philanthropic activities.

The business case for CSR has been summarized as reducing costs and risk, gaining competitive advantage, developing reputation and legitimacy, as well as creating win-win situations through synergistic value creation (Carroll and Shabana, 2010; Porter and Kramer, 2006). Said differently, CSR has been called long-term profitmaximizing (Carroll, 1999; Davis, 1973). The latter point has led some scholars to argue that the term should be reserved for those situations where business actually forgoes profits in the interests of society at large: If CSR implies earning money, it is not a moral decision, but just an economic strategy on a par with others (Hay, Stavins, and Vietor, 2005).

Our take is that CSR as an activity is the corporate attempt to negotiate its relationship to stakeholders and the public at large. It might include the process of mapping and evaluating demands from stakeholders, and the development and implementation of actions and policies to meet (or ignore) these demands. At a minimum, CSR focuses on the ways corporations handle economic, social and/or environmental issues. We will understand CSR communication as the ways that corporations communicate in and about this process; it is the corporate use of symbols and language regarding these matters.

\section{Criticism of CSR and CSR Communication}

Criticism of CSR and CSR communication is widespread and found on several levels. The touting of the business case for CSR has, for instance, met four critical arguments: First, critics have argued that there are some limits, that is, the market does not necessarily reward those that outperform their competition (Devinney, 2009; Mintzberg, 1983). Secondly, it has been argued that CSR should rather be seen as a niche strategy; it makes good business sense for some corporations in some sectors under certain circumstances. The business case is overblown; it is only after a product has passed the price and quality hurdles that CSR might be important (Vogel, 2005). There is plenty of evidence to show how the markets do not necessarily punish corporations that do not engage in CSR. "Unethical stocks" are still strong (Bendell and Bendell, 2007). Thirdly, building on the business case argument steers corporations towards particular issues and cases that are less costly and potentially profitable, while ignoring others that might be more pressing from society's point of view (Lee, 2008). Fourthly, tied to the latter, and perhaps the most damaging argument, is that the logic of the marketplace is incapable of effecting the radical transformation of corporations that is needed to make them sustainable (Kuhn and Deetz, 2008). A number of studies have concluded that talk about sustainability mostly means business as usual for corporations (Hopwood, Mellor, and O'Brien, 2005; Welford, 1997).

Critics of CSR, in general, can be found in many political camps. Free market liberalists, for instance, argue that the responsibility of corporations includes following rules and regulations. Other than this, the only corporate responsibility is to make money for the owners. If corporations start focusing on CSR, this will lead them astray. Business as an institution loses strength, the economic activity will be lower, and the state will lose tax revenues, which, in turn, weakens the welfare state. An associated argument is that politics should be left to politicians who have a legitimate role in tackling social problems that business managers do not have competence or legitimacy to address (Crook, 2005; Friedman, 1970; Henderson, 2001; Levitt, 1958).

From the other side of the political spectrum, other critics argue that CSR is an attempt to put a human face on capitalism in order to carry on with harmful practices. CSR is a form of manipulation to deceive the public (Beder, 1998; Christian Aid, 2004; Cloud, 2007; Woolfson and Beck, 2005). Critics point to discrepancies 
between what is said and what is done (Aras and Crowther, 2009; Cerin, 2002; Fougère and Solitander, 2009), and some see the discourse on CSR and the related concepts as "ideological movements that are intended to legitimize and consolidate the power of large corporations" (Banerjee, 2008, p. 51). The argument goes that CSR privileges narrow business interests and that external stakeholder wishes are curtailed through pretensions towards dialogue and so forth. Furthermore, corporations actually stand to undermine representative democracy in at least three fundamental ways: first by "promoting legislation that benefits corporations at the expense of individual citizens, [secondly by] the capturing of regulatory agencies by those whom the agencies were designed to regulate, and [thirdly by] the privatization of functions that have historically been the mandate of local, state, and federal governments" (Barley, 2007, p. 201).

Another type of criticism is directed at the limits of economic rationality and the possibilities to rectify such problems. Profit is the overarching motive for business and corporations will attempt to externalize its costs, that is, get others to pay for them (Bakan, 2004; Fisher and Lovell, 2003). CSR is only possible where a company's profits will be enhanced: it is impossible to escape the self-interested perspective; financial profits are sought at any cost (Munshi and Kurian, 2005). This means that business and the market need rules and regulations to keep them in check. If business is allowed to regulate itself, this will only result in short-term and fragmented measures. Thus, there is a need for international standards so that single companies cannot get away with less. If individual companies are to adopt CSR measures, they risk incurring costs that their competitors avoid. That individual companies take the lead is well and good, but only if their practices become institutionalized for the whole sector is it likely that CSR will produce great societal benefits (Zadek, 2001).

Similarly, critics argue for regulation by pointing out that it was not business itself that put child labor and environmental problems on the political agenda. When businesses today declare that they pay attention to their stakeholders, this is something forced upon them by civil society (Doane, 2004; Gray and Milne, 2004; Pendleton, 2004). While some trumpet the business argument for CSR and see the fear of reputation damage as an important driver, critics in this camp believe that it is not sufficient that the public, the media or nongovernmental organizations (NGOs) put pressure on the corporations. The problem is systemic and, in the current system, it is managerialism that prevails (Kuhn and Deetz, 2008). Writing on the topic of development, it has been argued that, while CSR has influenced the behavior of individual companies, it has left intact the fundamental values and systems: "In so far as the poor and marginalized share values that complement those universalized through globalization, there is a possibility for them to benefit from CSR" (Blowfield, 2005, p. 522). Problems arise, however, when the values diverge and systemic change is called for, since individual corporations cannot address the issue.

Bakan (2004) calls the corporation a pathological institution that follows its own interest regardless of the negative consequence created for others. CSR might lead to something good, but it cannot change this fundamental problem. Just as we need laws to protect us against murder and theft, we need laws to protect us against corporations - the institutionalized psychopaths that have no moral conviction but possess motives and power to create a lot of damage.

Still, we would like to argue that if the premise is that society wants to keep the business institution, we have to discuss CSR and recognize that CSR at least has an ethical potential. Currently, however, the following sentiment seems true: "CSR can work, for some people, in some places, on some issues, some of the time" (Newell, 2005, p. 556). Thus, there is a need to approach CSR in a way that is "simultaneously skeptical and embracing" (Devinney, 2009, p. 54).

Importantly, whatever position one takes on CSR, agreeing with the critics or not, we argue that communication plays a vital role. This holds, whether the researcher's purpose is critical - to point to shortcomings or unmask manipulation - or whether it is instrumental, as in seeking to help corporations improve their CSR communication. As will be illustrated throughout this volume, contributors vary in the extent to which they identify with the needs of corporations or not.

\section{The Importance of Communication}

Communication can be seen as important for organizations and their CSR work for a number of reasons, and the first one we would like to point to is epistemological. Our knowledge about the world is generated and socially shared through communication and is situated materially and historically. The notion of social constructionism (Berger and Luckmann, 1966) is now relatively uncontroversial, at least when it is coupled with a recognition that material structures do exist and the epistemological and ontological is seen as having a dialectic relationship.

An epistemological perspective rooted in social constructionism helps to temper theoretical tendencies toward naive realism. All knowledge and all truths implicate some kind of social agreement. It is through 
communication that ideas are accepted or rejected; truth is not discovered or unearthed and cannot be determined in any a priori way. Communication is involved when something is declared to be a fact, in the interpretation of that fact, and also in how it is used to justify action. This also extends to discourse communities that often try to deny that communication plays a role - for instance, economics and branches of science dealing with objective facts. Nevertheless, all types of knowledge must rest upon some kind of human consensus and, thus, there is a need for communication.

A social constructivist perspective maintains that communication is constructing and modifying reality, social conditions, and relationships. Variations of the theme language is power are thus commonplace (e.g., Bourdieu, 1991; Fairclough, 2001; Foucault, 1972). Recognizing the centrality of discourse has led to a so-called linguistic turn in many academic disciplines. We argue that communication studies are important in order to understand how the meaning of CSR is constructed, how it is implemented in organizations and used to achieve organizational goals. To this end, the present volume offers theories on discourse, internal communication, cognitive psychology, and reputation and rhetoric, among others. We believe that this can lead to a much more sophisticated understanding of communication than what is apparent in the current, mainstream CSR literature.

A second point: Is communication needed for CSR? Public relations, in particular, has often been criticized for being a shallow discipline intent at glossing up images of organizations. Some argue against placing the responsibility for CSR activities in the public relations department of an organization (Frankental, 2001). Often the basic idea that seems to be proposed is that businesses should concentrate on solving their tasks in a responsible manner. To communicate about CSR is suspect as it serves corporate self-interest, and corporations that flaunt their CSR engagements may even be punished in some markets. At the same time, several corporations readily admit that they see CSR primarily as a vehicle to enhance or protect their reputation (e.g., Vidaver-Cohen and Brønn, 2008). Such an instrumental use of CSR has been questioned by several authors (Husted and Allen, 2000; L'Etang, 1994). L'Etang argues that if a Kantian framework is adopted, then by implication: "Where self-interest plays a part in the motivation of the action, then that action is regarded as prudential and cannot be regarded as a morally right action" (L'Etang, 1996, p. 83). Thus, this latter point should prohibit corporate claims of "goodness." This, however, does not necessarily imply that corporations should stop doing "the right thing," but rather be careful when portraying their actions in moral terms (also see Chapter 9 on Ethics).

Some literature points out that CSR communication is not always beneficial for organizations since it may breed skepticism (Lindgreen and Swaen, 2010; Schlegelmilch and Pollach, 2005). There are good reasons, both of an ethical and pragmatic nature, for choosing a minimalist approach to CSR communication instead (Morsing et al., 2008). Still, we would argue that some form of communication is needed-actually, it cannot be avoided. It is not possible not to communicate with organizational publics, just as individuals cannot not communicate (Watzlawick, 1976). Silence on the matter of CSR is also a form of communication. In other words, communication is inescapable - it is implicated in CSR and business strategies whether management likes it or not.

While we certainly do not deny the existence of manipulative CSR communication, we also argue that communication provides the potential to help constitute stakeholder participation and ethical business practices. Communication theory offers models for stakeholder communication and collaboration that are not manipulative in intent, even when they are based in conflict, rather than consensus perspectives (Kuhn and Deetz, 2008). Throughout the book we hope to showcase more examples of this and other concepts, models and ideas from communication research that can enrich scholars' and organizations' work on or with CSR communication.

\section{Structure of the Book}

Since CSR is a global phenomenon, it also invites global attention. A unique feature of this book is the wide geographical range of contributors that are included. The book is edited by scholars from Norway, Australia and the United States, and contributions are from these countries as well as from Austria, Denmark, England, Germany, Malaysia, the Netherlands, Scotland, Singapore, Slovenia, Spain, Switzerland, Turkey, and New Zealand. In other words, the book is a truly international effort.

\section{Part One: Introduction}

In this first chapter we have given a short overview of the literature on CSR and CSR communication. In Chapter 2, two central management scholars, Sandra Waddock and Bradley K. Googins, both from the Carroll School of Management and the Center for Corporate Citizenship at Boston College in the United States, 
discuss what is arguably one of the most crucial challenges for CSR communication - communication about CSR often breeds public skepticism. With a distinct managerial approach, the authors discuss notions like transparency and trust, reputation and stakeholders, reporting and engagement, and foreshadow some of the book's crucial discussions that also pull from communication research.

\section{Part Two: Field overviews}

The second part of the book is devoted to field-specific literature reviews that draw together, discuss and extend the knowledge base on CSR communication. In addition to management, including business ethics and business and society, we discuss communication disciplines such as public relations, organizational communication, marketing, reputation management and rhetoric. Two of the reviewers of the book prospectus for this volume made the case that corporate communication should serve as the umbrella term that subsumed the mentioned subdisciplines. A similar argument could be made for use of the term strategic communication and it is also possible to point to instances where public relations has aspired to a status as the umbrella term. However, as we would like to discuss a plurality of perspectives, we have decided that the present approach would serve readers best. While there certainly are overlaps between the mentioned fields, they also have their own traditions and literature that make it worthwhile to discuss their insights in separate chapters.

The management literature on CSR does contain some work on CSR communication and this is analyzed in Chapter 3 by Jennifer L. Bartlett and Bree Devin, both of Queensland University of Technology, Australia. The chapter highlights some of the most important contributions that can be found in this literature, which is categorized as either belonging in the normative category, the strategic category or a category seeing CSR and CSR communication as a form of negotiated practice. The authors still argue that the discussion could be improved by incorporating perspectives from communication research.

Quite a few of the contributors define themselves as public relations scholars. In Chapter 4, Jennifer L. Bartlett of Queensland University of Technology in Australia reviews the body of public relations literature that has dealt with CSR. Some scholars actually conflate CSR and public relations; what is certain is that the concept has a relatively long history in public relations.

Chapter 5 focuses on organizational communication. Steve May of the University of North Carolina at Chapel Hill in the United States points out that the foundation for all external communication must be a commitment to internal communication.

The treatment of CSR in the field of marketing is the topic of Chapter 6, written by Peggy Simcic Brønn of BI Norwegian School of Management. Brønn highlights the implications for CSR communication stemming from the fact that marketing has adopted a new view of itself as an organizational function that impacts multiple stakeholders and has great influence on society.

In Chapter 7, Mark Eisenegger and Mario Schranz, both from the University of Zürich, Switzerland, discuss the field of reputation management and its relationship to CSR. An argument is made for paying more attention to the macrosocial environment and the role of the media when analyzing reputation formation.

In Chapter 8, Øyvind Ihlen from the University of Oslo, Norway, investigates two rhetorical concepts - the rhetorical situation and ethos - and discusses their implications for CSR communication.

\section{Part Three: CSR communication in action}

The third part of the book discusses CSR communication in action, first by looking at certain concepts and aspects that are important for CSR communication, and secondly, tools and processes. The concepts, aspects, tools and processes are not necessarily rooted in single academic disciplines, but found throughout the approaches mentioned earlier in Part Two. Concepts are understood as theoretical constructs with which we work when we theorize about CSR communication, while aspects are here thought of as something that influences CSR communication. Processes and tools are first and foremost something corporations themselves employ and/or are influenced by in their CSR communication.

\section{Concepts and aspects}

Chapter 9 starts the discussion with its focus on ethics. Jacquie L'Etang, Jairo Lugo-Ocando and Zeti Ahmad from Stirling University, Scotland, maintain that the strategic intent of CSR communication may compromise its success in certain political contexts.

In the chapter on reputation management, the authors show how risk of reputation loss is a crucial driver for 
CSR and CSR communication. In Chapter 10 Michael J. Palenchar and Tatjana M. Hocke from the University of Tennessee, United States, along with Robert L. Heath from the University of Houston, United States, probe deeper into the concept of risk. They maintain that CSR-based risk communication is fundamental to all discussions of how corporations should behave.

An essential building block for CSR and CSR communication is trust. In Chapter 11, Günter Bentele and Howard Nothhaft from the University of Leipzig in Germany see trust and credibility as essential communicative mechanisms for CSR.

Dialogue is often mentioned as a key concept in relation to CSR communication. In Chapter 12, Urša Golob and Klement Podnar from Ljubljana University, Slovenia, point out that the CSR dialogue needs to be transparent and lead to constructive responses.

Precisely, the notion of transparency has also been promoted heavily in the CSR literature. In Chapter 13, a critical discussion of this concept is presented by Majia H. Nadesan from Arizona State University in the United States. Nadesan argues that the current understanding is influenced by a neoliberal paradigm where self-regulation is the central technology, thus limiting the potential of the concept.

Another commonly-used concept in the literature is that of stakeholders. In Chapter 14, Juliana Raupp from the Free University of Berlin, Germany, writes about its relationship to CSR. She also contrasts the concept with that of publics found in the public relations literature and issues a call to the use of both concepts in a complementary manner.

While much of the literature on CSR seems to promote a one-size-fits-all approach, Chapter 15 takes issue with this. Through a discussion of the importance of sector, Augustine Pang, Angela Mak and Joanne Mui-Hean Lee, from Nanyang Technological University in Singapore point to important differences created by corporate size and business turnover, as well as corporate mission.

\section{Tools and processes}

Chapter 16 begins this section and focuses on issues management. The chapter, written by Robert L. Heath, University of Houston, United States, and Michael J. Palenchar, University of Tennessee, United States, presents the idea that issues management is fundamental to CSR and the organizational mission, as it helps the organization to adjust to the political economy.

One of the most popular and longstanding communication platforms for CSR has been the nonfinancial report. In Chapter 17, Elise Perrault Crawford and Cynthia Clark Williams, both from Bentley University, United States, discuss the benefits and drawbacks of this tool. Three generic reporting modes are identified.

Chapter 18 moves into the territory of information and communication technology with a focus on corporate use of the Internet and social media to communicate about CSR. Paul Capriotti from the University of Rovira Virgili, Spain, urges a move from the tactical to the strategic in the use of this platform.

Another more traditional tool is that of image advertising. Alan A. Pomering, University of Wollongong, Australia gives a brief history of this tool in Chapter 19 and discusses strategies to inhibit the formation of consumer skepticism.

A common way to work with CSR has been to engage in partnerships with NGOs. In Chapter 20, Melissa J. Bator and Cynthia Stohl, University of Santa Barbara, United States, point out that the new generation of these partnerships requires greater levels of symmetry between the corporation and the NGO.

In Chapter 21, Craig E. Carroll, University of North Carolina at Chapel Hill, United States, brings to the attention how the mass media is both an arena where discourse on CSR is formulated, as well as an actor in itself. Effects of CSR coverage are also discussed.

Chapter 22 similarly focuses on how NGOs function as communicative actors that influence the landscape in which corporations operate. Sarah E. Dempsey, University of North Carolina at Chapel Hill, United States, discusses the communicative labor of NGOs themselves.

In Chapter 23, Stefan Wehmeier, University of Vienna, Austria, and Friederike Schultz, University of Amsterdam, the Netherlands, focus on storytelling. In particular, the theoretical lens of social constructivism is used to relate the ideas to narrativity and sensemaking to CSR communication that is often normative and moralistic.

\section{Part Four: Commentaries and conclusions}


The final section of the book consists of contributions from communication and management scholars that comment on both the main topic of the book, as well as our attempts to demonstrate how communication disciplines have something to bring to the management table and are, indeed, important in themselves.

The first commentary, Chapter 24, is given by two communication professors - Lars Thøger Christensen, University of Southern Denmark, and George Cheney, University of Texas at Austin, United States. Christensen and Cheney criticize some of the discussions and perspectives on communication, dialogue, and consistency and authenticity found throughout the book. The most important critical point of theirs is probably that the volume does not pay enough attention to how CSR can be seen as communication and what communication does to CSR.

The second commentary, Chapter 25, is presented by two Australian-based communication scholars, Judy Motion from the University of New South Wales and Shirley Leitch from Swinburne University of Technology. In their commentary they extend on the contributions in the handbook and focus in particular on the conceptualization of the socia/ in CSR, to whom corporations are responsible and with whom they communicate. One of their basic arguments is that there is a need for a clearer understanding and a more rigorous approach to this keyword.

Chapter 26 sees Güler Aras, Professor in finance and accounting at the Yildiz Technical University, Turkey and David Crowther, Professor of corporate social responsibility at De Montfort University in the UK discuss, in particular, the technological development as well as reporting practices and link this discussion to the volume's contributions. One of their conclusions is that CSR and reporting is a mechanism of myth-creation.

The last of the commentaries, Chapter 27, is written by scholars from organizational studies - David Grant and Daniel Nyberg from the University of Sydney in Australia. Grant and Nyberg agree to the proposition that communication studies are well-positioned to help further an understanding of the role and significance of CSR discourse and its impacts. At the same time, they, like Motion and Leitch in Chapter 25, maintain that the issue of power should have been given more attention.

Finally, the very last chapter, written by the volume's editors, draws conclusions about the possibilities and perils of CSR communication based on the contributions in the book. We return to the discussion of the importance of CSR and communication, principles for good CSR communication, the organization-environment interface, platforms for communication, as well as language and meaning. In addition we touch upon some crucial issues that have not been discussed thoroughly in the book - power and culture.

\section{References}

Aras, G., and Crowther, D. (2009). Corporate sustainability reporting: A study in disingenuity? Journal of Business Ethics, (87) , 279-288.

Aras, G., and Crowther, D. (eds). (2010). A handbook of corporate governance and social responsibility. Aldershot, UK: Gower.

Bakan, J. (2004). The corporation: The pathological pursuit of profit and power. London, UK: Constable.

Banerjee, S. B. (2008). Corporate social responsibility: The good, the bad and the ugly. Critical Sociology, (34) (1), 51-79.

Barley, S. R. (2007). Corporations, democracy, and the public good. Journal of Management Inquiry, (16) (3), 201-215.

Beder, S. (1998). Global spin: The corporate assault on environmentalism. London, UK: Chelsea Green Publishing Company.

Bendell, J., and Bendell, M. (2007). Facing corporate power. In S. K. May, G. Cheney and J. Roper (eds), The debate over corporate social responsibility (pp. 59-73). New York, NY: Oxford University Press.

Berger, P., and Luckmann, T. (1966). The social construction of reality: A treatise in the sociology of knowledge. London, UK: Penguin Books.

Bernays, E. L. (1975). Social responsibility of business. Public Relations Review, (1) (3), 5-16.

Birth, G., Illia, L., Lurati, F., et al. (2008). Communicating CSR: Practices among Switzerland's top 300 companies. Corporate Communications: An International Journal, (13) (2), 182-196. 
Blowfield, M. (2005). Corporate social responsibility: Reinventing the meaning of development? International Affairs, (81) (3), 515-524.

Blowfield, M., and Murray, A. (2008). Corporate responsibility: A critical introduction. New York, NY: Oxford University Press.

Bourdieu, P. (1991). Language and symbolic power(G. Raymond and M. Adamson, trans.). Cambridge, UK: Polity.

BP. (2010). Sustainability review 2009. London, UK: BP.

Branco, M. C., and Rodrigues, L. L. (2006). Communication of corporate social responsibility by Portuguese banks: A legitimacy theory perspective. Corporate Communications: An International Journal, (11) (3), 232-248.

Buchholz, R. A., and Rosenthal, S. B. (1999/2002). Social responsibility and business ethics. In R. E. Frederick (ed.), A companion to business ethics (pp. 303-321). Oxford, UK: Blackwell Publishers.

Burchell, J. (ed.). (2008). The corporate social responsibility reader. London, UK: Routledge.

Burchell, J., and Cook, J. (2006). It's good to talk? Examining attitudes towards corporate social responsibility dialogue and engagement processes. Business Ethics: A European Review, (15) (2), 154-170.

Burchell, J., and Cook, J. (2008). Stakeholder dialogue and organisational learning: Changing relationships between companies and NGOs. Business Ethics: A European Review, (17) (1), 35-46.

Campbell, D., Shrives, P., and Bohmbach-Saager, H. (2001). Voluntary disclosure of mission statements in corporate reports: Signaling what to whom?. Business and Society Review, (106) (1), 65-87.

Carroll, A. B. (1979). A three-dimensional conceptual model of corporate performance. Academy of Management Review, (4) (4), 497-505.

Carroll, A. B. (1991). The pyramid of corporate social responsibility: Toward the moral management of organizational stakeholders. Business Horizons, (34) (4), 39-48.

Carroll, A. B. (1999). Corporate social responsibility: Evolution of a definitional construct. Business and Society, (38) (3), 268-295.

Carroll, A. B., and Shabana, K. M. (2010). The business case for corporate social responsibility: A review of concepts, research and practice. International Journal of Management Reviews, (12) (1), 85-105.

Cerin, P. (2002). Communication in corporate environmental reports. Corporate Social Responsibility and Environmental Management, (9) , 46-66.

Chaudhri, V., and Jian, W. (2007). Communicating corporate social responsibility on the Internet: A case study of the top 100 information technology companies in India. Management Communication Quarterly, (21) (2), 232-247.

Chen, S., and Bouvain, P. (2009). Is corporate responsibility converging? A comparison of corporate responsibility reporting in the USA, UK, Australia, and Germany. Journal of Business Ethics, (87) , $299-317$.

Chevron. (2010). The value of partnership: 2009 corporate responsibility report. San Ramon, CA: Chevron Corporation.

China National Petroleum Corporation. (2010). 2009 corporate social responsibility report: Caring for energy, caring for you. Beijing, China: CNPC.

Christian Aid. (2004). Behind the mask: The real face of corporate social responsibility. London, UK: Christian Aid.

Clarke, J., and Gibson-Sweet, M. (1999). The use of corporate social disclosures in the management of reputation and legitimacy: A cross sectoral analysis of UK top 100 companies. Business Ethics: A European Review, (8) (1), 5-13.

Cloud, D. L. (2007). Corporate social responsibility as oxymoron: Universalization and exploitation at Boeing. In S. K. May, G. Cheney and J. Roper (eds), The debate over corporate social responsibility (pp. 219-231). New York, NY: Oxford University Press. 
Commission of the European Communities. (2001). Green paper: Promoting a European framework for corporate social responsibility. Brussels.

Crane, A., Matten, D., and Spence, L. J. (eds). (2008). Corporate social responsibility: Readings and cases in a global context. New York, NY: Routledge.

Crane, A., McWilliams, A., Matten, D., et al. (2008a). The corporate social responsibility agenda. In A. Crane, A. McWilliams, D. Matten, et al. (eds), The Oxford handbook of corporate social responsibility (pp. 3-15). New York, NY: Oxford University Press.

Crane, A., McWilliams, A., Matten, D., et al. (eds). (2008b). The Oxford handbook of corporate social responsibility. New York, NY: Oxford University Press.

Crook, C. (2005, January 22). The good company. The Economist, pp. 3-4.

Crowther, D., and Rayman-Bacchus, L. (2004a). Introduction: Perspectives on corporate social responsibility. In D. Crowther and L. Rayman-Bacchus (eds), Perspectives on corporate social responsibility (pp. 1-17). Aldershot, UK: Ashgate.

Crowther, D., and Rayman-Bacchus, L. (eds). (2004b). Perspectives on corporate social responsibility. Aldershot, UK: Ashgate.

Davis, K. (1973). The case for and against business assumption of social responsibilities. Academy of Management Journal, (16) (2), 312-322.

Deetz, S. A. (1992). Democracy in an age of corporate colonization: Developments in communication and the politics of everyday life. New York, NY: State University of New York Press.

Den Hond, F., de Bakker, F. G. A., and Neergaard, P. (eds). (2007). Managing corporate social responsibility in action: Talking, doing and measuring. Aldershot, UK: Ashgate.

Devinney, T. M. (2009). Is the socially responsible corporation a myth? The good, the bad, and the ugly of corporate social responsibility. Academy of Management Perspectives, (23) (2), 44-56.

Doane, D. (2004). Good intentions - bad outcomes? The broken promise of CSR reporting. In A. Henriques and J. Richardson (eds), The triple bottom line: Does it all add up? (pp. 81-88). London, UK: Earthscan.

Du, S., Bhattacharya, C. B., and Sen, S. (2010). Maximizing business returns to corporate social responsibility (CSR): The role of CSR communication. International Journal of Management Reviews, (12) (1), 8-19.

Elkington, J. (1998). Cannibals with forks: The triple bottom line of twenty-first-century business. Gabriola Island, Canada: New Society.

ExxonMobil. (2010). 2009 corporate citizenship report. Irving, TX: Exxon Mobil.

Fairclough, N. (2001). Language and power(2nd edn). Harlow, UK: Longman.

Fisher, C., and Lovell, A. (2003). Business ethics and values. Harlow, UK: Financial Times/Prentice Hall.

Fombrun, C. J. (2005). Building corporate reputation through CSR initiatives: Evolving standards. Corporate Reputation Review, (8) (1), 7-11.

Ford Motor. (2010). Blueprint for sustainability: Our future works: Sustainability report 2009/10. Dearborn, MI: Ford.

Foucault, M. (1972). The archaeology of knowledge and the discourse of language. New York, NY: Pantheon Books.

Fougère, M., and Solitander, N. (2009). Against corporate responsibility: Critical reflections on thinking, practice, content and consequences. Corporate Social Responsibility and Environmental Management, (16) (4), 217-227.

Frankental, P. (2001). Corporate social responsibility - a PR invention? Corporate Communications: An International Journal, (6) (1), 18-23.

Friedman, M. (1970, September 13). The social responsibility of business is to increase its profits. New York Times Magazine, pp. 122-126. 
General Electric Company. (2010). 2009 citizenship report: Renewing responsibilities. Fairfield, CT: General Electric Company.

Golob, U., and Bartlett, J. L. (2007). Communicating about corporate social responsibility: A comparative study of CSR reporting in Australia and Slovenia. Public Relations Review, (33) (1), 1-9.

Gray, R., and Milne, M. (2004). Towards reporting on the triple bottom line: Mirages, methods and myths. In A. Henriques and J. Richardson (eds), The triple bottom line: Does it all add up? (pp. 70-80). London, UK: Earthscan.

Habisch, A., Jonker, J., Wegner, M., and Schmidpeter, R. (eds). (2005). Corporate social responsibility across Europe. Berlin, Germany: Springer.

Hagen, Ø. (2008). Seduced by their proactive image? On using auto communication to enhance CSR. Corporate Reputation Review, (11) (2), 130-144.

Hartman, L., Rubin, R., and Dhanda, K. (2007). The communication of corporate social responsibility: United States and European Union multinational corporations. Journal of Business Ethics, (74) (4), 373-389.

Hay, B. L., Stavins, R. N., and Vietor, R. H. K. (eds). (2005). Environmental protection and the social responsibility of firms: Perspectives from law, economics, and business. Washington, DC: Resources for the Future.

Heath, R. L., and Palenchar, M. (2008). Strategic issues management: Organizations and public policy challenges (2nd edn). London, UK: Sage.

Henderson, D. (2001). Misguided virtue: False notion of corporate social responsibility. London, UK: Institute of Economic Affairs.

Henriques, A., and Richardson, J. (eds). (2004). The triple bottom line: Does it all add up? London, UK: Earthscan.

Hillenbrand, C., and Money, K. (2007). Corporate responsibility and corporate reputation: Two separate concepts or two sides of the same coin? Corporate Reputation Review, (10) (4), 261-277.

Hopwood, B., Mellor, M., and O'Brien, G. (2005). Sustainable development: Mapping different approaches. Sustainable Development, (13) (1), 38-52.

Husted, B. W., and Allen, D. B. (2000). Is it ethical to use ethics as strategy? Journal of Business Ethics, (27), $21-31$.

Idowu, S. O., and Filho, W. L. (eds). (2009). Global practices of corporate social responsibility. Berlin, Germany: Springer.

ING Group. (2010). Corporate responsibility report 2009: ING in society. Amsterdam, The Netherlands: ING Group.

Jose, A., and Lee, S.-M. (2007). Environmental reporting of global corporations: A content analysis based on website disclosures. Journal of Business Ethics, (72) (4), 307-321.

Kolk, A. (2003). Trends in sustainability reporting by the Fortune Global 250. Business Strategy and the Environment, (12), 279-291.

Korten, D. C. (2001). When corporations rule the world (2nd edn). Bloomfield, CN: Kumarian Press.

KPMG. (2008). KPMG International survey of corporate responsibility reporting 2008. Amsterdam, The Netherlands: KPMG.

Kuhn, T., and Deetz, S. (2008). Critical theory and corporate social responsibility: Can/should we get beyond cynical reasoning? In A. Crane, A. McWilliams, D. Matten, et al. (eds), The Oxford handbook of corporate social responsibility (pp. 173-196). New York, NY: Oxford University Press.

L'Etang, J. (1994). Public relations and corporate social responsibility: Some issues arising. Journal of Business Ethics, (13) , 111-123.

L'Etang, J. (1996). Corporate responsibility and public relations ethics. In J. L'Etang and M. Pieczka (eds), Critical perspectives in public relations (pp. 82-105). London, UK: International Thomson Business Press. 
Lee, M.-D. P. (2008). A review of the theories of corporate social responsibility: Its evolutionary path and the road ahead. International Journal of Management Reviews, (10) (1), 53-73.

Levitt, T. (1958). The dangers of social responsibility. Harvard Business Review, (36) , 41-50.

Lindgreen, A., and Swaen, V. (2010). Corporate social responsibility. International Journal of Management Reviews, (12) (1), 1-7.

Livesey, S. M., and Kearins, K. (2002). Transparent and caring corporations? A study of sustainability reports by the Body Shop and Royal Dutch/Shell. Organization and Environment, (15) (3), 233-258.

Lockett, A., Moon, J., and Visser, W. (2006). Corporate social responsibility in management research: Focus, nature, salience and sources of influence. Journal of Management Studies, (43) (1), 115-136.

Matten, D., Crane, A., and Chapple, W. (2003). Behind the mask: Revealing the true face of corporate citizenship. Journal of Business Ethics, (45) , 109-120.

May, S. K. (2011). Corporate social responsibility: Vice or virtue? Cambridge, UK: Polity Press.

May, S. K., Cheney, G., and Roper, J. (eds). (2007). The debate over corporate social responsibility. New York, NY: Oxford University Press.

McWilliams, A., Siegel, D. S., and Wright, P. M. (2006). Corporate social responsibility: Strategic implications. Journal of Management Studies, (43) (1), 1-18.

Mintzberg, H. (1983). The case for corporate social responsibility. Journal of Business Strategy, (4) (2), 3-15.

Mitchell, N. J. (1989). The generous corporation: A political analysis of economic power New Haven, CT: Yale University Press.

Moreno, A., and Capriotti, P. (2009). Communicating CSR, citizenship and sustainability on the web. Journal of Communication Management, (13) (2), 157-175.

Morsing, M., and Beckmann, S. C. (eds). (2006). Strategic CSR communication. Copenhagen, Denmark: Juristog Økonomforbundets Forlag.

Morsing, M., and Schultz, M. (2006). Corporate social responsibility communication: Stakeholder information, response and involvement strategies. Business Ethics: A European Review, (15) (4), 323-338.

Morsing, M., Schultz, M., and Nielsen, K. U. (2008). The 'Catch 22' of communicating CSR: Findings from a Danish study. Journal of Marketing Communications, (14) (2), 97-111.

Munshi, D., and Kurian, P. (2005). Imperializing spin cycles: A postcolonial look at public relations, greenwashing, and the separation of publics. Public Relations Review, (31) (4), 513-520.

Newell, P. (2005). Citizenship, accountability and community: the limits of the CSR agenda. International Affairs, (81) (3), 541-557.

Nielsen, A. E., and Thomsen, C. (2007). Reporting CSR - what and how to say it? Corporate Communications: An International Journal, (12) (1), 25-40.

Okoye, A. (2009). Theorising corporate social responsibility as an essentially ontested oncept: Is a definition necessary? Journal of Business Ethics, (89) (4), 613-627.

Painter-Morland, M. (2006). Triple bottom-line reporting as social grammar: Integrating corporate social responsibility and corporate codes of conduct. Business Ethics: A European Review, (15) (4), 352-364.

Pendleton, A. (2004). The real face of corporate social responsibility. Consumer Policy Review, (14) (3), 77-82.

Perrini, F. (2005). Building a European portrait of corporate social responsibility reporting. European Management Journal, (23) (6), 611-627.

Perrini, F., Pogutz, S., and Tencati, A. (eds). (2006). Developing corporate social responsibility: A European perspective. Cheltenham, UK: Edward Elgar.

Podnar, K. (2008). Guest editorial: Communicating corporate social responsibility. Journal of Marketing Communications, (14) (2), 75-81. 
Porter, M. E., and Kramer, M. R. (2006). Strategy and society: The link between competitive advantage and corporate social responsibility. Harvard Business Review, (December), 78-92.

Raupp, J., Jarolimek, S., and Schultz, F. (eds). (2010). Handbuch Corporate Social Responsi bility: Kommunikationswissenschaftliche Grundlagen und methodische Zugänge. Wiesebaden, Germany: VS Verlag.

Scherer, A. G., and Palazzo, G. (eds). (2008). Handbook of research on global corporate citizenship. Cheltenham, UK: Edward Elgar.

Schlegelmilch, B. B., and Pollach, I. (2005). The perils and opportunities of communicating corporate ethics. Journal of Marketing Management, (21) (3/4), 267-290.

Shell Group. (2010). Sustainability report: Royal Dutch Shell Plc sustainability report 2009. The Hague, The Netherlands: Royal Dutch Shell.

Smith, N. C. B., Bhattacharya, C. B., Vogel, D., and Levine, D. I. (eds). (2010). Global challenges in responsible business. New York, NY: Cambridge University Press.

Svensson, G., Wood, G., Singh, J., and Callaghan, M. (2009a). A cross-cultural construct of the ethos of the corporate codes of ethics: Australia, Canada and Sweden. Business Ethics: A European Review, (18) (3), 253-267.

Svensson, G., Wood, G., Singh, J., and Callaghan, M. (2009b). Implementation, communication and benefits of corporate codes of ethics: An international and longitudinal approach for Australia, Canada and Sweden. Business Ethics: A European Review, (18) (4), 389-407.

The Economist. (2008, January 19). Ethical capitalism: How good should your business be? The Economist, $12-13$.

Vidaver-Cohen, D., and Brønn, P. S. (2008). Corporate citizenship and managerial motivation: Implications for business legitimacy. Business and Society Review, (113) (4), 441-475.

Vogel, D. (2005). The market for virtue: The potential and limits of corporate social responsibility. Washington, DC: Brookings Institution.

Waddock, S. (2001). Integrity and mindfulness: Foundations of corporate citizenship. In J. Andriof and M. Mclntosh (eds), Perspectives on corporate citizenship (pp. 26-38). Sheffield, UK: Greenleaf Publishing.

Waddock, S. (2004). Parallel universes: Companies, academics, and the progress of corporate citizenship. Business and Society Review, (109) (1), 5-42.

Wang, J., and Chaudhri, V. (2009). Corporate social responsibility engagement and communication by Chinese companies. Public Relations Review, (35) (3), 247-250.

Watzlawick, P. (1976). How real is 'real'? Confusion, disinformation, communication. New York, NY: Random House.

Welford, R. (ed.). (1997). Hijacking environmentalism: Corporate responses to sustainable development. London, UK: Earthscan.

Werther, W. B., and Chandler, D. (2006). Strategic corporate social responsibility: Stakeholders in a global environment. London, UK: Sage.

Windsor, D. (2001). Corporate citizenship: Evolution and interpretation. In J. Andriof and M. Mclntosh (eds), Perspectives on corporate citizenship (pp. 39-52). Sheffield, UK: Greenleaf Publishing.

Wood, D. J. (1991a). Corporate social performance revisited. Academy of Management Review, (16) (4), 691-718.

Wood, D. J. (1991b). Social issues in management: Theory and research in corporate social performance. Journal of Management, (17) (2), 383-406.

Woolfson, C., and Beck, M. (2005). Corporate social responsibility in the international oil industry. In C. Woolfson and M. Beck (eds), Corporate social responsibility failures in the oil industry (pp. 1-13). Amityville, NY: Baywood.

Zadek, S. (2001). The civil corporation: The new economy of corporate citizenship. London, UK: Earthscan. 
Zorn, T. E., and Collins, E. (2007). Is sustainability sustainable? Corporate social responsibility, sustainable business, and management fashion. In S. K. May, G. Cheney and J. Roper (eds), The debate over corporate social responsibility (pp. 405-416). New York, NY: Oxford University Press.

\section{Cite this article}

Ihlen, Øyvind, Jennifer L. Bartlett and Steve May. "Corporate Social Responsibility and Communication." The Handbook of Communication and Corporate Social Responsibility. Ihlen, Øyvind, Jennifer L. Bartlett and Steve May (eds). Blackwell Publishing, 2011. Blackwell Reference Online. 03 November 2014

<http://www.blackwellreference.com/subscriber/tocnode.html?id=g9781 444336344_chunk_g97814443363442>

\section{Copyright}

Blackwell Publishing and its licensors hold the copyright in all material held in Blackwell Reference Online. No material may be resold or published elsewhere without Blackwell Publishing's written consent, save as authorised by a licence with Blackwell Publishing or to the extent required by the applicable law. 